\title{
Epidemiological, Clinical and Management of Benign Prostatic Hypertrophia in Urologie Department in N'Djamena, Chad
}

\author{
Kimassoum Rimtebaye1, Edouard Hervé Moby Mpah², Arya Zarif Agah Tashkand1, \\ Franklin Danki Sillong ${ }^{3}$, Mignagnal Kaboro' ${ }^{1}$, Lamine Niang ${ }^{4}$, Serigne Magueye Gueye ${ }^{4}$ \\ ${ }^{1}$ National General Referal Hospital of N'Djamena, N'Djamena, Chad \\ ${ }^{2}$ Laquintinie Hospital of Douala, Douala, Cameroon \\ ${ }^{3}$ Protestant Hospital of N'Gaoundéré, N'Gaoundéré, Cameroon \\ ${ }^{4}$ Grand Yoff General Hospital of Dakar, Dakar, Senegal \\ Email: melinarim@yahoo.fr
}

How to cite this paper: Rimtebaye, K., Mpah, E.H.M., Tashkand, A.Z.A., Sillong, F.D., Kaboro, M., Niang, L. and Gueye, S.M. (2017) Epidemiological, Clinical and Management of Benign Prostatic Hypertrophia in Urologie Department in N'Djamena, Chad. Open Journal of Urology, 7, 9-15. http://dx.doi.org/10.4236/oju.2017.71002

Received: November 21, 2016

Accepted: January 9, 2017

Published: January 12, 2017

Copyright $\odot 2017$ by authors and Scientific Research Publishing Inc. This work is licensed under the Creative Commons Attribution International License (CC BY 4.0).

http://creativecommons.org/licenses/by/4.0/

\begin{abstract}
Aim: To determine the epidemiological, clinical, paraclinical characteristics and assess the result of surgical treatment of benign prostatic hyperplasia $(\mathrm{BPH})$ in the urological department. Patients and Method: It is a retrospective descriptive study of 757 patient samples whose BPH diagnosis was pronounced and have benefited of the open surgery in urology department from January 2006 to December 2010. The variables studied were sociodemographical, clinical, paraclinical, therapeutical and the follow up. Those variables were: arterial tension, sonography, consultation reasons and hospitalization, the data provided rectal touch, the comorbidity, the prostatic specific antigen (PSA), other blood tests, urinary tests, medical management surgical treatment, the causes of death and the complications. Results: during the study period, 2406 patients were hospitalized, from them 1472 (61.18\%) for low urinary tract diseases where 757 for $\mathrm{BPH}$. The mean age was 64.18 years. The acute urine retention was the main cause of hospitalizations and consultations (51.51\%). The rectal touch Helped in diagnosing $96.43 \%$ of cases. PSA in $74.10 \%$, the sonography evaluated the volume of the prostate and the complications on the upper urinary tract, kidney dilatation and stones. An urgent evacuation of acute retention of urine in the bladder was done in $74.10 \%$, a medical treatment was done in $33.47 \%$. The open surgery was done in $66.47 \%$. The evolution was good for 703 (92.86\%), 54 died (7.14\%) and the causes were various (anemia, hyperglycemia, HIV ...). Conclusion: The BHP was the first reason of consultation and hospitalization in urology department in N'Djamena. Its diagnosis was done after the analysis of a beam clinical and paraclinical arguments. In the absence of an endoscopic resection column,
\end{abstract}


open surgery was the only surgical treatment.

\section{Keywords}

Benign Prostatic Hyperplasia, Prostate, Urology, X Ray, Surgery

\section{Introduction}

Benign prostatic hyperplasia $(\mathrm{BPH})$ is a benign tumor which is developed from the prostate gland [1]. Its etiology is not clearly known, despite many researches on it. But its hormonal dependence on testosterone is undeniable. In the world, BHP is the main cause of pathologies of the lower urinary tract in men. The incidence of the BHP in male increases according to age, from 40 years old (2.7\%) to 80 years (50\%) [2] [3] [4] [5]. The symptomatology of the BHP is not specific but it is the same for all urine troubles in lower urinary tract. The diagnosis of $\mathrm{BPH}$ is based on the clear analysis of a wide beam of clinical and paraclinical arguments [6]. The recent discovery of PSA (prostate specific antigen) is the most important time in the etiological BHP diagnosis [7]. The gold standard of the surgical treatment of the $\mathrm{BPH}$ is the transurethral resection of the prostate (TURP) despite this, the open surgery has its place in the surgical arsenals (treatment) in many African countries that do not have an endoscopic column and even in European countries when the prostate weight is greater than 100 grams.

The main objective of this study is to determine the epidemiological, clinical, paraclinical characteristics and assess the result of surgical treatment of BHP in the department of urology in N'Djamena, Chad.

\section{Patients and Methods}

The study was retrospective, descriptive and was done from January 2006 to December 2010 in the urology department of National General Referral Hospital of N'Djamena in Chad. There were 1472 patients with lower urinary tract pathologies and the diagnosis of BHP was retained for 757 of them. We collected the data from: folders of investigations, patient's registers, hospital and surgical records.

The patients were either directly consulted in urology or referred by a colleague. It was excluded from the study that, those who were not followed up the urology department and those whose hospitalization records were incomplete. Were included, patients who have been suffering of BHP and who were followed up in the urology department. Before beginning the study, we had obtained the authorization from the head of the faculty of Health, Science of the University of N'Djamena in Chad, from the national comity of ethics, from the headquarters of the hospital and from the head of department of urology. We also obtained the agreement of the patients before including them into the study and using their pictures only for illustration in order to improve the scientific research. 
The variables studied were: Epidemiological and social: age, profession, residence, marital status; number of wives. Clinical variables: motive of consultation, duration of symptomatology, evaluation of general health, presence of the bladder globe, data of rectal touch. Paraclinical variables: blood test (PSA, hemoglobin and hematocrit; creatininemia; glycaemia); urinary test and ultrasound). Therapeutic variables: emergency medical or surgical gesture, medical or surgical treatment. Evaluative variables were: recovery, causes of complications and deaths. The data were exploited with Word and Excel.

\section{Results}

The frequency of the BHP was 51.42\% $(\mathrm{n}=757)$. The mean age was 64.18 [40 and 105]. The patients in the range age of [51 - 60], [61 - 70] and [71 - 80] suffered more, respectively in the proportions of $36.72 \%, 23.69 \%$ and $33.69 \%$. Farmers and breeders were many: $581(76.75 \%)$. They mostly lived in urban area 490 (64.72\%), were married: $92.20 \%(\mathrm{n}=698)$ and $416(59.59 \%)$ of them had more than 2 wives at the diagnosis moment. The main reason of consultation was the acute urine retention (Table 1) and Picture 1 . They began the consultation from 1 to 5 years later, after the apparitions of the first symptoms. Some patients had a high level of glycaemia $(\mathrm{n}=37)$, of high blood pressure (HBP) ( $\mathrm{n}=$ 86) and 13 were HIV positive, 597 were healthy, 3 patients had only one testicle located on the left side. The data of the rectal touch were reported on Table 2, 79 patients $(10.44 \%)$ had a rate of hemoglobin under $10 \mathrm{~g} / \mathrm{dl}$, and the urine test

Table 1. Motive of consultation.

\begin{tabular}{ccc}
\hline Motives & $\mathbf{n}$ & $\%$ \\
\hline Urinary retention & 390 & 51.51 \\
Total dysuria & 150 & 19.81 \\
Burning micturition & 112 & 14.79 \\
Pollakiuria & 80 & 10.56 \\
Urge micturition & 60 & 7.92 \\
Sensation of incomplete emptying & 58 & 7.66 \\
Hematuria & 53 & 7 \\
+ more signs & 24 & 3.17 \\
\hline
\end{tabular}

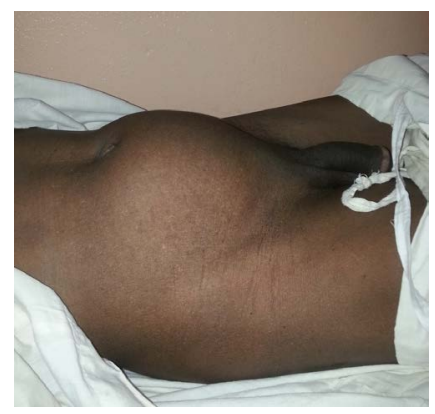

Picture 1. Acute urine retention. 
Table 2. Repartition according to the rectal touch result.

\begin{tabular}{ccc}
\hline Rectal touch result & number & $\%$ \\
\hline Regular contour & 741 & 97.89 \\
Irregular contour & 16 & 2.11 \\
Hard, stony consistency & 730 & 96.43 \\
Stony consistency & 27 & 3.57 \\
Presence of median furrow & 160 & 21.14 \\
Absence of median furrow & 597 & 78.86 \\
Presence of nodule & 24 & 3.17 \\
Absence of nodule & 733 & 96.83 \\
\hline
\end{tabular}

was sterile for 703 patients. The PSA rate was reported on a table (Table 2). And the Table 3 gave the ultrasound result. Complications found were: bladder stones $(n=48)$, inguinal hernia by effort $(n=36)$, renal failure $(n=18)$ and hemorrhoids $(n=12)$. The main emergency gesture done was bladder evacuation $(\mathrm{n}=561)$. Medical treatment consisted in using Alpha blocker (Alfuzocine) for $253(33.47 \%)$ patients, a phytotherapy for 250 (33.07\%), a 5-alpha-reductase inhibitor (chibroproscar) for 27 (3.59\%), association between alpha blocker and phytotherapy for 227 (29.87). Open surgery of prostate was done on 570 patients. The evolution was good for 703 (92.86\%), 54 died (7.14\%) and the causes were: anemia $(\mathrm{n}=18)$, hyperglycemia $(\mathrm{n}=12)$, HAT $(\mathrm{n}=15)$, HIV complications $(n=5)$. For 4 other cases the causes were unknown.

\section{Discussion}

The BPH was a frequent pathology on consultation and hospitalization in urology department in HGRN and represented $61.18 \%$ of hospitalization reasons during the period of study. Those hospitalizations were done for patients who had principal symptoms: complete urine retention, dysuria and anemia. In other African countries, the frequency varies, like in Mali it was $86.3 \%$. The mean age of patients was 64.18 but It varies according to countries and studies; as compared in African against European ones [8] [9] [10]. We noticed that BPH is the first male urinary pathology. Furthermore, in Chad polygamists were many because polygamy was tolerated by society. So many Chadians said "we beat a woman by another woman". It means that: if your wife behaves badly, you can get another one. The complete urine retention was the main motive of consultation and hospitalization of our study. In the population of the patients who suffered from BHP according to J.-C. Baron et al. [6], the incidence of the complete urine retention varies from $0.4 \%$ to $6 \%$ per year. Many others authors had found the same result [11] [12] [13]. That also means people ignore the first symptoms of BPH which were: urgentury, dysuria, urinary infection, burning micturition. So a solution to handle this matter is by sensitizing people on $\mathrm{BPH}$.

In our point of view, HIV, diabetes and HBP cannot only be considered as a 
Table 3. Repartition of patients according PSA result.

\begin{tabular}{ccc}
\hline PSA (ng) & Number & $\%$ \\
\hline$<4$ & 516 & 68.13 \\
5 to 10 & 69 & 9.16 \\
11 to 30 & 69 & 9.16 \\
21 to 30 & 51 & 6.77 \\
$>30$ & 51 & 6.77 \\
Total & 757 & 100 \\
\hline
\end{tabular}

Normal value: inferior to $4 \mathrm{ng} / \mathrm{ml}$.

simple comorbidity but as aggravating factors because they increase the rate of death when people suffer from BHP according to our study. The urine test of many patients was sterile in Chad because most of them were self-medicated with antibiotics before coming to the hospital.

About $31.7 \%$ of patients had an increase of the rate of the PSA, this may be caused by an adenocarcinoma of prostate, an infection with bacteria, or the complication of bilharzia. This situation can be clarified by another future study.

For medical treatment of BHP, we frequently prescribe an alpha-blocker once or in association with phytotherapy. This is what has been done by most authors [14] [15] [16] [17]. If the result of medical treatment is not good, we only performan open surgery at this period because endoscopic column is notavailable. Nowadays the TURP is the gold standard of the surgery of the BHP in the world [10]. Despite this, open surgery is often used in African countries [18] because of the lack of the endoscopic column.

\section{Conclusion}

The BHP was the first cause of consultation and hospitalization in urology department in Chad. The complete urineretention was the first symptom and the most complication of BHP. People go late for BHP consultation, that situation can only be resolved by sensitizing people. The aggravating factors were: HIV, HAT and diabetes. The rate of recovery after open surgery was $92.86 \%$.

\section{References}

[1] Fitzpatrick, J.M. (2006) The Natural History of Benign Prostatic Hyperplasia. JM Fitzpatrick. BJU Int, 97, Suppl 2, 3-6.

[2] Lacoin, F., Fourcade, R.O., Rouprêt, M., Slama, A., Le Fur, C., Michel, E., et al. (2013) Perceptions de l'hypertrophie bénigne de la prostate par le patient et le médecin généraliste-Etude Trophée (Perceptions of Benign Prostatic Hyperplasia According to the Perspective of Patients and General Practitioners-The Trophée Study). Progrès en Urologie, 23, 50-57. https://doi.org/10.1016/j.purol.2012.10.003

[3] Jacobsen, S.J., Girman, C.J. and Lieber, M.M. (2001) Natural History of Benign Prostatic Hyperplasia. Urology, 58, 5-16.

https://doi.org/10.1016/S0090-4295(01)01298-5

[4] Anderson, J.B., Roehrborn, C.G., Schalken, J.A. and Emberton, M. (2001) The Pro- 
gression of Benign Prostatic Hyperplasia: Examining the Evidence and Determining the Risk. European Urology, 39, 390-399.

https://doi.org/10.1159/000052475

[5] Emberton, M., Andriole, G.L., de la Rosette, J., Djavan, B., Hoefner, K., Navarrete, R.V., et al. (2003) Benign Prostatic Hyperplasia: A Progressive Disease of Aging Men. Urology, 61, 267-273. https://doi.org/10.1016/S0090-4295(02)02371-3

[6] Baron, J.C. and Rousselot, F. (2004) Arguments de décision de changement de traitement dans l'hypertrophie bénigne de la prostate. Annales d'Urologie, 38, 5356.

[7] Botchorishvili, G., Matikainen, M.P. and Lilja, H. (2009) Early Prostate-Specific Antigen Changes and the Diagnosis and Prognosis of Prostate Cancer. Current Opinion in Urology, 19, 221-226. https://doi.org/10.1097/MOU.0b013e32832a2d10

[8] Kambou, T., Zango, B., Ekoue, F., Traore, A.C., Bonkoungou, B., Ouattara, T. and Sano, D. (2006) Traitement chirurgical de l'hypertrophie bénigne de la prostate: $\mathrm{Au}$ $\mathrm{CHU}$ sanou souro de bobo-dioulasso (Burkina Faso) résultats à court et moyen terme-A propos de 190 cas. Médecined Afrique Noire, 53, 605-612.

[9] Fall, P.A., Gueye, S.M., Ndoye, A.K., Diao, D., Thiam, O.B.K., Abdallahi, M.O.C., et al. (2002) Mortalité et Morbidité précoces après adénomectomie prostatique par voie transvésicale. African Journal of Urology, 8, 20-23.

[10] Zango, B., Kambou, T. and Sanou, A. (2002) La résection transurétrale de la prostate à l'hôpital Sanou Souro de Bobo-Dioulasso: A propos de 68 cas. African Journal of Urology, 8, 1-5.

[11] Wong, M.Y.C., Lim, Y.L. and Foo, K.T. (1994) Transurethral Resection of the Prostate for Benign Prostatic Hyperplasia-A Local Review. Singapore Medical Journal, 35, 357-359.

[12] Ahmed Gadam, I., Nuhu, A. and Aliyu, S. (2012) Ten-Year Experience with Open Prostatectomy in Maiduguri. ISRN Urology, 2012, Article ID: 406872.

[13] Hill, AG. And Njoroge, P. (2002) Suprapubic Transvesical Prostatectomy in a Rural Kenyan Hospital. East African Medical Journal, 79, 65-67. https://doi.org/10.4314/eamj.v79i2.8902

[14] Madersbacher, S., Alivizatos, G., Nordling, J., Sanz, C.R., Emberton, M. and de la Rosette, J.J. (2004) EAU 2004 Guidelines on Assessment, Therapy and Follow-Up of Men with Lower Urinary Tract Symptoms Suggestive of Benign Prostatic Obstruction (BPH Guidelines). European Urology, 46, 547-554.

https://doi.org/10.1016/j.eururo.2004.07.016

[15] Evans, C.P., Fleshner, N., Fitzpatrick, J.M. and Zlotta, A.R. (2005) An EvidenceBased Approach to Understanding the Pharmacological Class Effect in the Management of Prostatic Diseases. BJU International, 95, 743-749. https://doi.org/10.1111/j.1464-410X.2005.05390.x

[16] McConnell, J.D., Roehrborn, C.G., Bautista, O.M., Andriole Jr., G.L., Dixon, C.M., Kusek, J.W., et al. (2003) Medical Therapy of Prostatic Symptoms (MTOPS) Research Group. The Long-Term Effect of Doxazosin, Finasteride, and Combina- tion Therapy on the Clinical Progression of Benign Prostatic Hyperplasia. The New England Journal of Medicine, 349, 2387-2398. https://doi.org/10.1056/NEJMoa030656

[17] Barkin, J., Guimaraes, M., Jacobi, G., Pushkar, D., Taylor, S. and van Vierssen Trip, O.B. (2003) Alpha-Blocker Therapy Can Be Withdrawn in the Majority of Men Following Initial Combination Therapy with the Dual 5alpha-Reductase Inhibitor Dutasteride. European Urology, 44, 461-466.

https://doi.org/10.1016/S0302-2838(03)00367-1 
[18] Kpatcha, T., Tchangai, B., Tengue, K., Alassani, F., Botcho, G., Darre, T., et al. (2016) Experience with Open Prostatectomy in Lomé, Togo. Open Journal of Urology, 6, 73-79.

Submit or recommend next manuscript to SCIRP and we will provide best service for you:

Accepting pre-submission inquiries through Email, Facebook, LinkedIn, Twitter, etc. A wide selection of journals (inclusive of 9 subjects, more than 200 journals)

Providing 24-hour high-quality service

User-friendly online submission system

Fair and swift peer-review system

Efficient typesetting and proofreading procedure

Display of the result of downloads and visits, as well as the number of cited articles Maximum dissemination of your research work

Submit your manuscript at: http://papersubmission.scirp.org/

Or contact oju@scirp.org 